\title{
ARHGAP22 wt Allele
}

National Cancer Institute

\section{Source}

National Cancer Institute. ARHGAP22 wt Allele. NCI Thesaurus. Code C131765.

Human ARHGAP22 wild-type allele is located within 10q11.22-q11.23 and is

approximately $226 \mathrm{~kb}$ in length. This allele, which encodes Rho GT Pase-activating protein

22 , is involved in the conversion of GTP to GDP. 